\title{
Effects of seabird nitrogen input on biomass and carbon accumulation after 50 years of primary succession on a young volcanic island, Surtsey
}

\author{
N. I. W. Leblans ${ }^{1,2}$, B. D. Sigurdsson ${ }^{2}$, P. Roefs ${ }^{1}$, R. Thuys ${ }^{1}$, B. Magnússon ${ }^{3}$, and I. A. Janssens ${ }^{1}$ \\ ${ }^{1}$ Univ. of Antwerp, Dept. of Biology, 2610 Wilrijk, Belgium \\ ${ }^{2}$ Agric. Univ. of Iceland, Hvanneyri 311 Borgarnes, Iceland \\ ${ }^{3}$ Icelandic Inst. of Nat. Hist., 210 Gardabaer, Iceland
}

Correspondence to: N. I. W. Leblans (niki.leblans@ua.ac.be)

Received: 27 March 2014 - Published in Biogeosciences Discuss.: 5 May 2014

Revised: 2 October 2014 - Accepted: 7 October 2014 - Published: 17 November 2014

\begin{abstract}
What happens during primary succession after the first colonizers have occupied a pristine surface largely depends on how they ameliorate living conditions for other species. For vascular plants the onset of soil development and associated increase in nutrient (mainly nitrogen; N) and water availability is especially important. Here, we report the relationship between $\mathrm{N}$ accumulation and biomass and ecosystem carbon (C) stocks in a 50-year-old volcanic island, Surtsey, Iceland, where N stocks are still exceptionally low. However, a 28-year-old seagull colony on the island provided nutrient-enriched areas, which enabled us to assess the relationship between $\mathrm{N}$ stock and biomass and ecosystem $\mathrm{C}$ stocks across a much larger range in $\mathrm{N}$ stock. Further, we compared areas on shallow and deep tephra sands as we expected that deep-rooted systems would be more efficient in retaining $\mathrm{N}$. The sparsely vegetated area outside the colony had accumulated $0.7 \mathrm{~kg} \mathrm{~N} \mathrm{ha}^{-1} \mathrm{yr}^{-1}$, which was ca. $50-60 \%$ of the estimated $\mathrm{N}$ input rate from wet deposition. This approximates values for systems under low $\mathrm{N}$ input and bare dune habitats. The seagulls have added, on average, $47 \mathrm{~kg} \mathrm{Nha}^{-1} \mathrm{yr}^{-1}$, which induced a shift from belowground to aboveground in ecosystem $\mathrm{N}$ and $\mathrm{C}$ stocks and doubled the ecosystem $\mathrm{N}$-use efficiency, determined as the ratio of biomass and $\mathrm{C}$ storage per unit $\mathrm{N}$ input. Soil depth did not significantly affect total $\mathrm{N}$ stocks, which suggests a high $\mathrm{N}$ retention potential. Both total ecosystem biomass and $\mathrm{C}$ stocks were strongly correlated with $\mathrm{N}$ stock inside the colony, which indicated the important role of $\mathrm{N}$ during the first steps of primary succession. Inside the colony, the
\end{abstract}

ecosystem biomass $\mathrm{C}$ stocks (17-27 ton $\mathrm{C} \mathrm{ha}^{-1}$ ) had reached normal values for grasslands, while the soil organic carbon (SOC) stocks (4-10 ton $\mathrm{Cha}^{-1}$ ) were only a fraction of normal grassland values. Thus, it will take a long time until the SOC stock reaches equilibrium with the current primary production, during which conditions for new colonists may change.

\section{Introduction}

Primary succession, the chain of processes in which an ecosystem develops on an unvegetated substrate that lacks a developed soil (Vitousek et al., 1989; Walker and Del Moral, 2003), is a complex process that depends on the interplay of numerous factors, both biotic and abiotic (Raab et al., 2012). Most studies on primary succession of volcanic islands and inland volcanoes have focused on community changes in flora and fauna (e.g. Walker et al., 2003; Magnússon et al., 2009; Marteinsdottir et al., 2010), but fewer have looked into changes in underlying environmental drivers for community change (Walker and Del Moral, 2003). Yet, such drivers often play a crucial role in the onset of ecosystem development (Kögel-Knabner et al., 2013) and are also often a function of long-term ecosystem processes, such as soil development (Long et al., 2013a).

The build-up of biomass leads to the accumulation of soil organic carbon (SOC), which is an indicator of soil development (Kögel-Knabner et al., 2013). SOC greatly improves 
the physical and chemical properties of soil, such as water holding capacity and ion exchange capacity, thereby enhancing nutrient retention and exchange (Deluca and Boisvenue, 2012). As the successful germination, establishment and growth rate of many species strongly depends on these soil properties, the presence of well-developed soils forms an ecological threshold for many species (Long et al., 2013b). Consequently, biomass and carbon (C) accumulation form an important step in the course of primary succession that enables less stress-tolerant and often more productive species to arrive (Grime, 1977). A positive reciprocal relationship can be expected between SOC (and its source, biomass production) and nutrient accumulation ( $\mathrm{Li}$ and Han, 2008). On the one hand, SOC facilitates the retention of nutrients, while on the other hand, improved nutrient supply has a positive effect on plant biomass in all terrestrial systems (Gruner et al., 2008), which leads to increased SOC accumulation. Therefore, we expected the amount of nutrient input to be an important determinant of biomass and $\mathrm{C}$ accumulation during primary succession. Once the system has reached a sufficient level of fertility for more productive, secondary colonizers to establish, SOC production will be enhanced and a positive feedback loop between biomass production (SOC) and nutrient accumulation will initiate. Subsequently, the rate of primary succession has been shown to increase following such fertility change (Olff et al., 1993; Vitousek et al., 1993; Sigurdsson and Magnússon, 2010).

Of all nutrients, nitrogen $(\mathrm{N})$ is most frequently the limiting nutrient for plant growth in high latitude terrestrial ecosystems due to the adverse effect of cold temperatures on biogeochemical processes (Aerts and Chapin, 2000; Reich and Oleksyn, 2004; Storm and Suess, 2008), which is even more pronounced on young substrates (Vitousek et al., 1993; Vitousek and Farrington, 1997; Elser et al., 2007). Therefore, $\mathrm{N}$ is expected to be strongly linked with SOC accumulation during primary succession of young volcanic islands at high latitudes.

Surtsey is a volcanic island which surfaced during a submarine eruption between 1963 and 1967 and has, from the very beginning, been strictly protected for research (Baldurson and Ingadóttir, 2007). This makes it an exceptionally suitable location to study the natural course of successional processes. As Surtsey is still a young volcanic island, its vegetation is expected to be $\mathrm{N}$ limited (Vitousek et al., 1993; Vitousek and Farrington, 1997; Elser et al., 2007). Nitrogen has indeed been identified as a strong limiting factor for plant growth and succession at Surtsey (Hendriksson, 1976; Magnússon and Magnússon, 2000), and the N : P ratio of five dominant plant species on Surtsey generally indicates a strong $\mathrm{N}$ limitation $(\mathrm{N}: \mathrm{P}<14$; Aerts and Chapin, 2000) (Thuys et al., 2014).

The importance of nutrients became very visible after the establishment of a seabird colony in 1986 (mainly lesser black-backed gull, Larus fuscus) on the SW side of the island (Magnússon and Magnússon, 2000; Fig. 1). Seabirds

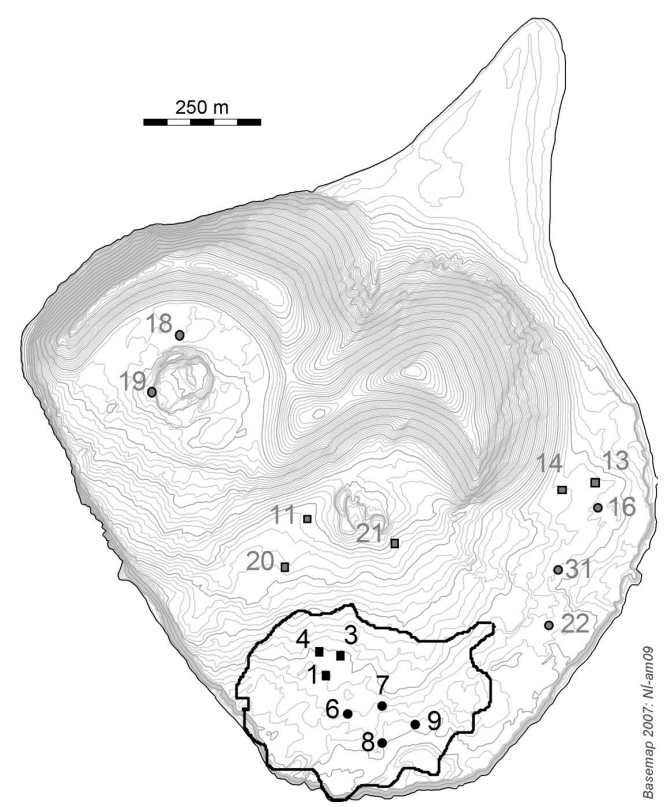

Figure 1. Location of the permanent study plots on Surtsey that were used in this study, shown on a topographical map from 2007. Contour intervals are $2 \mathrm{~m}$, the highest point on the island is $152 \mathrm{~m}$ a.s.l. The Eastern crater is located close to plots 18 and 19, the Western crater is located close to plot 21 . North of the craters, a high rim of palagonite tuff was formed. The dense vegetation within the seabird colony in 2012 is marked with a black line (approximation from aerial and satellite images, by Anette Th. Meier; Magnússon et al., 2014). Grey is outside seabird colony; black is inside colony; squares are deep tephra sand; circles are shallow tephra sand.

are known to transfer nutrients, primarily ammonium and nitrate, from sea to land (Polis and Hurd, 1996; Anderson and Polis, 1999; Ellis et al., 2006; Nie et al., 2014). The effect of enhanced nutrient inputs has been studied by comparing surfaces that were unaffected by seabirds with the seabirdcolonized area (Magnússon and Magnússon, 2000; Magnússon et al., 2009; Sigurdsson and Magnússon, 2010). In the seabird colony, the rapid increase in soil $\mathrm{N}$ elicited subsequent increases in plant cover and species richness. These earlier studies did, however, not attempt to quantify the rate of $\mathrm{N}$ accumulation or study the development of the whole ecosystem biomass, $\mathrm{C}$ or nutrient stocks.

Within the seabird colony at Surtsey, the earlier studies have revealed diverging successional trajectories of vascular plant communities between areas with deep tephra sand or with surfacing lava rocks (Magnússon and Magnússon, 2000). This has become even more pronounced during the past decade (Del Moral and Magnússon, 2014), showing faster development of species richness and plant cover in seabird colony plots on deep tephra sand.

The main goal of this study was to quantify the rate of $\mathrm{N}$ accumulation in different permanent study plots on Surtsey and investigate how this compared to changes in the whole 
ecosystem biomass and C stocks. Despite previous studies revealing drastic effects of the seabird-derived $\mathrm{N}$ input on the ecosystem structure and functions on Surtsey (Magnússon and Magnússon, 2000; Kristinsson and Heidmarsson, 2009; Magnússon et al., 2009; Petersen, 2009; Sigurdsson and Magnússon, 2010; Del Moral and Magnússon, 2014; Thuys et al., 2014) no data exist on the annual $\mathrm{N}$ input coming from seabirds, except from a coarse estimate from Magnússon et al. (2009), who combined excretion and food models for the lesser black-backed gull (Larus fuscus) and the herring gull (Larus argentatus), derived from Hahn et al. (2007) and nest counts on Surtsey. We therefore attempted to obtain a more precise approximation of the seabird derived $\mathrm{N}$ input by measuring total $\mathrm{N}$ stocks and correcting for the total colonization time. The null hypothesis was that the annual net $\mathrm{N}$ accumulation rate inside the seabird colony amounts to ca. 30 ton $\mathrm{Nha}^{-1}$, as was estimated by Magnússon et al. (2009).

Further, we tested four hypotheses in detail:

(i) (i)

Atmospheric $\mathrm{N}$ deposition is the main $\mathrm{N}$ source outside the seabird colony. As we do not expect that this sparsely vegetated area is very efficient in $\mathrm{N}$ retention, large amounts of $\mathrm{N}$ can be lost due to leaching during large rain events. Field observations in different ecosystems with low $\mathrm{N}$ input rates, as is the case outside the colony, revealed an average $\mathrm{N}$ retention of $75 \%$ (Thomas et al., 2013). Therefore, we hypothesized that total $\mathrm{N}$ stocks outside the seabird colony would approximate $75 \%$ of the total estimated accumulated atmospheric $\mathrm{N}$ deposition during the past 50 years.

(ii) (ii)Among similar vegetation types, those with deeper root systems were shown to be more effective in avoiding $\mathrm{N}$ leaching losses than their shallower rooting equivalents (Bowman et al., 1998). On Surtsey, most N that leaches through the upper substrate layer is removed from the system by seeping into cracks and fissures in the lava bedrock. Therefore, we hypothesized that plots on deep tephra sand show higher $\mathrm{N}$ retention compared to plots on shallow tephra sand.

(iii) (iii)Nutrient rich systems are known to invest relatively more in aboveground plant growth than nutrient poor systems (e.g. Warembourg and Estelrich, 2001; Wang et al., 2008; Gao et al., 2011; Zhou et al., 2014). Therefore we expected to find a shift from belowground to aboveground biomass, $\mathrm{C}$ and $\mathrm{N}$ stocks inside the seagull colony, compared to outside the colony.

(iv) (iv)An important factor in the process of soil development, the process in which bedrock material is transformed into a soil with defined horizons by a combination of climate, biota, topography, parent material and time, is the accumulation of SOC (Kögel-Knabner et al.,
2013). As SOC is a product of biomass degradation, we hypothesized that increased productivity of the seagull colony enhances the rate of soil development.

\section{Materials and methods}

\subsection{Site description}

Samples were collected on Surtsey $\left(63^{\circ} 18^{\prime} 11 \mathrm{~N}\right.$, $20^{\circ} 36^{\prime} 17 \mathrm{~W}$ ) in mid-July 2012 and mid-July 2013. The island surfaced during an eruption between 1963 and 1967 and was $1.41 \mathrm{~km}^{2}$ in 2004 . Surtsey is the youngest island of the Vestmannaeyjar archipelago, which is located on the insular shelf $32 \mathrm{~km}$ off the south coast of Iceland. The archipelago constitutes a separate volcanic system, which initiated activity around 100000 years before present (Jakobsson, 1979). Climate conditions on the archipelago are humid sub-arctic. Average temperatures between 1971 and 2000 during winter and summer were $1.5-2$ and $10^{\circ} \mathrm{C}$, respectively (Icelandic Meteorological Office). Total annual precipitation during the same period was on average $1600 \mathrm{~mm}$ and fell mainly between October and March. The prevailing wind direction is East, and wind speed exceeds hurricane force $\left(>32.7 \mathrm{~m} \mathrm{~s}^{-1}\right)$ on average 15 days per year (Icelandic Meteorological Office). The bedrock of the higher parts of Surtsey consists of basalt tuff, whereas in lower parts it is made out of basaltic lava (Jakobsson, 1968). The island is still too young to have well-developed soils. The lava is partly filled with tephra sand and silt, which originates from eruptions, erosion of the bedrock material and aeolian transport from the mainland. The vegetation on these sandy areas is dominated by Honkenya peploides and Leymus arenaria (Magnússon et al., 2014; Stefansdottir et al., 2014). In 1986, a seabird colony of lesser black-backed gulls (Larus fuscus) was established in a confined area on the SW edge of the island (Petersen, 2009), and has been expanding in size ever since. The dominant plant species inside the seagull colony are Poa pratensis, P. аппиа and Festuca richardsonii (Magnússon et al., 2009).

\subsection{Sample sites}

Between 1990 and 1995 , permanent $10 \times 10 \mathrm{~m}$ plots were established on Surtsey to survey ecosystem changes in and outside the seabird colony (Fig. 1). Out of these plots, we selected 18 representative plots inside and outside the seabird colony, partly on deep ( $\geq 30 \mathrm{~cm}$ deep) and partly on shallow tephra sand $(<30 \mathrm{~cm}$ deep). Ten plots were situated outside the colony (of which six were sampled in 2012 and four in 2013) and eight plots were situated inside the colony (of which four were sampled in 2012 and four in 2013). In every case, half of the plots were located on shallow and the other half on deep tephra sand. We placed three subplots $(20 \times 50 \mathrm{~cm})$ for destructive sampling $0.5 \mathrm{~m}$ outside the 
southern edge of each permanent plot $\left(n_{\text {outsidecolony }}=30\right.$; $n_{\text {inside colony }}=24$ ).

\subsection{Vegetation and soil sampling}

During the two expeditions to Surtsey, all vascular plants were cut in each subplot $(20 \times 50 \mathrm{~cm})$ and subsequently separated into species in the field. Next, the litter layer was collected from the same plots, except in the more vegetated seabird colony, where it was collected from a $20 \times 20 \mathrm{~cm}$ subplot within the harvest plot. Soil was then sampled from where the litter had been removed using a hand-driven soil corer $(8.67 \mathrm{~cm}$ diameter). Consecutive soil samples of $5 \mathrm{~cm}$ depth were taken down to $30 \mathrm{~cm}$ depth or until the bedrock was reached. All samples were air dried awaiting further analyses.

\subsection{Sample preparation and chemical analysis}

Fine roots (diameter $<2 \mathrm{~mm}$ ) were picked manually from soil samples in the laboratory, for maximum $60 \mathrm{~min}$ per sample. In cases where litter was found during the sorting process, it was added to the litter sample. The root-free soil was sieved through a $2 \mathrm{~mm}$ sieve in order to separate the coarse soil fraction $(>2 \mathrm{~mm})$ from the sand, silt and clay particles $(<2 \mathrm{~mm})$. All fractions, roots, soil particles $<2 \mathrm{~mm}$ and soil particles $>2 \mathrm{~mm}$, were dried for $48 \mathrm{~h}$ at $40^{\circ} \mathrm{C}$. The coarse fraction was assumed to contain only a marginal amount of organic $\mathrm{C}$ or N. In few cases where the sample weight was too small for analysis ( $<1 \mathrm{~g}$ dry weight), samples from the same layer were merged with neighbouring subplots within the same plot. The basaltic tephra sand in Surtsey does not contain any carbonates (mineral $\mathrm{C}$ ), and inorganic $\mathrm{N}$ was assumed to be negligible compared to the total soil organic nitrogen (SON) stock (Ponnameruma et al., 1967), and was therefore not measured.

After drying all biomass samples for $48 \mathrm{~h}$ at $40^{\circ} \mathrm{C}$, dry mass of all aboveground vascular plants (separated in monocotyledons, eudicotyledons and ferns and horsetails), moss, litter and fine roots (in 0-5, 5-10, 10-20 and 20-30 cm depth layers) was weighed.

For each sample, $1 \mathrm{~g}$ dry mass (DM) was milled using a ball mill (Retsch MM301 Mixer Mill, Haan, Germany) and then total $\mathrm{C}$ and $\mathrm{N}$ concentrations were analysed by dry combustion with a Macro Elemental Analyser (model vario MAX $\mathrm{CN}$, Hanau, Germany). Concentration of $\mathrm{C}$ and $\mathrm{N}$ was determined for all aboveground vascular plant parts together, litter, moss, roots and soil particles $(<2 \mathrm{~mm})$ per aforementioned soil layer. Soil samples were then dried at $105^{\circ} \mathrm{C}$ for $48 \mathrm{~h}$ and weighed again to determine the correct DM.

\subsection{C and N stocks and accumulation rates}

The $\mathrm{C}$ and $\mathrm{N}$ stocks in aboveground vascular plant biomass, litter and moss were estimated by multiplying total DM with the respective concentrations and were expressed per unit

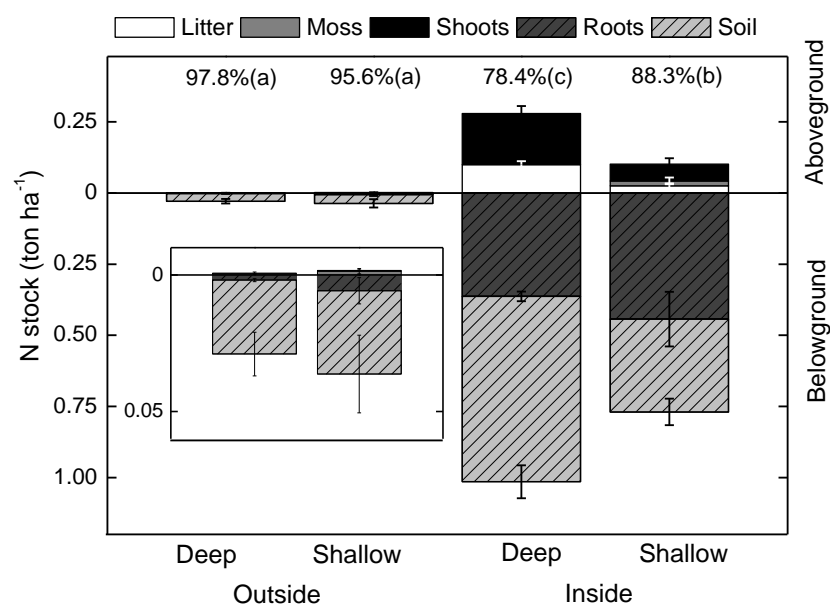

Figure 2. Mean $( \pm \mathrm{SE})$ values of the biomass stock and carbon stock of litter, shoots, roots (to $30 \mathrm{~cm}$ depth) and SOC (to $30 \mathrm{~cm}$ depth) in four ecosystem types on Surtsey. The inserted graphs give the values outside the seabird colony in more detail. "Shoots" include aboveground living vascular plant parts. Statistical results are shown in Table 1. Percentages above the graph indicate the $\%$ of total $\mathrm{N}$ that is located belowground. Letters show statistical differences.

area. The $\mathrm{C}$ and $\mathrm{N}$ stocks in roots and soil particles $(<2 \mathrm{~mm})$ per unit area were calculated per soil layer by multiplying total DM $<2 \mathrm{~mm}$ of the soil layer with the respective concentrations.

For the plots outside the seabird colony, $\mathrm{N}$ accumulation rate was calculated by dividing the total $\mathrm{N}$ stock by the number of years since the start of accumulation (from 1963, the year of the surfacing of the island), assuming a constant $\mathrm{N}$ accumulation rate. For the plots inside the seabird colony, a separate estimate was made for the $\mathrm{N}$ accumulation rate of seabird derived $\mathrm{N}$. Therefore, the total $\mathrm{N}$ stock of plots inside the colony was first subtracted by the amount of total $\mathrm{N}$ stock outside the colony, assuming that this equals the non-bird $\mathrm{N}$ input over the whole island. Subsequently, the remaining N stock was divided by the years since seagulls started to breed within $1000 \mathrm{~m}^{2}$ of each plot (Magnússon and Magnússon, 2000; Magnússon et al., 2009).

\subsection{Data analyses}

Differences in ecosystem $\mathrm{N}$ stocks, biomass and $\mathrm{C}$ stocks were tested with a two-way ANOVA in R software ( $R$ Development Core Team, 2012), with seabird colony (yes or no) and tephra depth (deep or shallow) as fixed variables. Differences in $\mathrm{N}$ accumulation rate and proportional distribution of SON and root $\mathrm{N}$ per soil depth layer were tested in the same way. The correlations between biomass stocks, ecosystem $\mathrm{C}$ stocks and root/shoot $(\mathrm{R} / \mathrm{S})$ ratios and ecosystem $\mathrm{N}$ stocks were tested separately for plots inside and outside the seagull colony. A correlation test was applied using the "Spearman" method whenever the assumptions of homoscedasticity 
Table 1. Results of the two-way ANOVA for N stock, biomass stock, $\mathrm{C}$ stock and $\mathrm{N}$ accumulation rate, using seabird colony and tephra depth as fixed variables. "Shoots" include all aboveground living plant parts, "Living" includes "Shoots" and "Roots" and "Dead" includes "Litter" and SON or SOC. Significant source variables $(p<0.05)$ with respect to ecosystem parts are indicated with an asterisk: ns is $p>0.05, * p$ is $0.05-0.01, * * p$ is $0.01-0.001, * * * p<0.001$.

\begin{tabular}{|c|c|c|c|c|c|c|c|c|c|c|c|c|c|c|}
\hline \multirow[b]{2}{*}{ Source } & \multicolumn{8}{|c|}{$\mathrm{N}$ stock (ton ha ${ }^{-1}$ ) } & \multicolumn{5}{|c|}{ Biomass stock (ton ha ${ }^{-1}$ ) } & \multirow[b]{2}{*}{ Total } \\
\hline & Shoots & Roots & Moss & Living & Litter & SON & Dead & Total & Shoots & Roots & Moss & Living & Litter & \\
\hline \multicolumn{15}{|l|}{ Colony $\times$ depth } \\
\hline Df Numerator & 1 & 1 & 1 & 1 & 1 & 1 & 1 & 1 & 1 & 1 & 1 & 1 & 1 & 1 \\
\hline Df Denominator & 15 & 15 & 15 & 15 & 15 & 15 & 15 & 15 & 15 & 15 & 15 & 15 & 15 & 15 \\
\hline$F$ value & 5.82 & 0.24 & 1.62 & 0.03 & 13.63 & 7.20 & 9.56 & 3.29 & 1.83 & 0.10 & 1.29 & 0.21 & 8.02 & 0.50 \\
\hline$p$ value & $*$ & $\mathrm{~ns}$ & ns & ns & $* *$ & * & ** & ns & $\mathrm{ns}$ & ns & ns & ns & * & $\mathrm{ns}$ \\
\hline \multicolumn{15}{|l|}{ Colony } \\
\hline Df Numerator & - & 1 & 1 & 1 & - & - & - & 1 & 1 & 1 & 1 & 1 & - & 1 \\
\hline Df Denominator & - & 17 & 17 & 17 & - & - & - & 17 & 17 & 17 & 17 & 17 & - & 17 \\
\hline$F$ value & - & 0.00 & 1.15 & 40.40 & - & - & - & 83.14 & 10.95 & 23.30 & 0.89 & 23.86 & - & 25.03 \\
\hline$p$ value & - & $* * *$ & $\mathrm{~ns}$ & $* * *$ & - & - & - & $* * *$ & $* *$ & $* * *$ & ns & $* * *$ & - & *** \\
\hline \multicolumn{15}{|l|}{ Depth } \\
\hline Df Numerator & - & 1 & 1 & 1 & - & - & - & 1 & 1 & 1 & 1 & 1 & - & 1 \\
\hline Df Denominator & - & 16 & 16 & 16 & - & - & - & 16 & 16 & 16 & 16 & 16 & - & 16 \\
\hline$F$ value & - & 0.28 & 1.87 & 0.01 & - & - & - & 2.32 & 1.91 & 0.04 & 2.29 & 0.12 & - & 0.34 \\
\hline$p$ value & - & ns & $\mathrm{ns}$ & ns & - & - & - & ns & ns & ns & ns & ns & - & ns \\
\hline
\end{tabular}

\begin{tabular}{|c|c|c|c|c|c|c|c|c|c|c|c|c|c|c|}
\hline \multicolumn{15}{|c|}{$\begin{array}{l}\text { Colony effect on deep } \\
\text { tephra sand }\end{array}$} \\
\hline Df Numerator & 1 & - & - & - & 1 & 1 & 1 & - & - & - & - & - & 1 & - \\
\hline Df Denominator & 8 & - & - & - & 8 & 8 & 8 & - & - & - & - & - & 8 & - \\
\hline$F$ value & 0.00 & - & - & - & 11.97 & 0.00 & 0.00 & - & - & - & - & - & 17.35 & - \\
\hline$p$ value & $* * *$ & - & - & - & * & $* * *$ & $* * *$ & - & - & - & - & - & ** & - \\
\hline \multicolumn{15}{|c|}{$\begin{array}{l}\text { Colony effect on shallow } \\
\text { tephra sand }\end{array}$} \\
\hline Df Numerator & 1 & - & - & - & 1 & 1 & 1 & 1 & - & - & - & - & 1 & - \\
\hline Df Denominator & 7 & - & - & - & 7 & 7 & 7 & 7 & - & - & - & - & 7 & - \\
\hline$F$ value & 3.21 & - & - & - & 5.02 & 0.00 & 0.00 & 3.21 & - & - & - & - & 1.20 & - \\
\hline$p$ value & ns & - & - & - & Ns & $* * *$ & $* * *$ & ns & - & - & - & - & ns & - \\
\hline \multicolumn{15}{|c|}{ Depth effect outside colony } \\
\hline Df Numerator & 1 & - & - & - & 1 & 1 & 1 & - & - & - & - & - & 1 & - \\
\hline Df Denominator & 8 & - & - & - & 8 & 8 & 8 & - & - & - & - & - & 8 & - \\
\hline$F$ value & 0.53 & - & - & - & 1.83 & 0.02 & 0.02 & - & - & - & - & - & 0.00 & - \\
\hline$p$ value & ns & - & - & - & Ns & $\mathrm{ns}$ & ns & - & - & - & - & - & ns & - \\
\hline \multicolumn{15}{|c|}{ Depth effect inside colony } \\
\hline Df Numerator & 1 & - & - & - & 1 & 1 & 1 & - & - & - & - & - & 1 & - \\
\hline Df Denominator & 7 & - & - & - & 7 & 7 & 7 & - & - & - & - & - & 7 & - \\
\hline$F$ value & 5.16 & - & - & - & 11.97 & 6.57 & 8.68 & - & - & - & - & - & 8.95 & - \\
\hline$p$ value & ns & - & - & - & * & * & * & - & - & - & - & - & * & - \\
\hline
\end{tabular}

(tested with residual plot) or linearity (tested with the runs test; Turlach, 2011; Trapletti et al., 2012; Zeileis et al., 2012) were not met. Null hypotheses were rejected when $p<0.05$.

\section{Results}

\subsection{Ecosystem N stock and distribution}

The total $\mathrm{N}$ stock outside and inside the seabird colony after 50 years of island development and ca. 26-27 years after the first lesser black-backed gull colonization differed significantly by a factor of approximately 30 (Fig. 2, Table 1). Soil depth had no significant effect on total accumulated $\mathrm{N}$ stock (in biomass and soil), neither outside nor inside the seabird colony. Also, the $\mathrm{N}$ stock of the living compartment (shoots, roots and moss together) and of shoots, roots and moss separately did not differ between deep and shallow tephra sand.
However, inside the seagull colony, the $\mathrm{N}$ stock of the dead OM (organic material) compartment (litter and SON combined), and of the litter and SON separately, was significantly higher in deep tephra sand than in shallow tephra sand on lava (Fig. 2, Table 1).

Of the total $\mathrm{N}$ stock outside the colony, approximately $96 \%$ of the $\mathrm{N}$ was stored belowground in roots and SON, while within the colony this was reduced to about 78 and $88 \%$ in deep and shallow tephra sand, respectively (Fig. 2).

The amount of $\mathrm{N}$ stored as SON was 24 (on deep tephra sand) and 11 (on shallow tephra sand) times higher inside than outside the colony (Fig. 2, Table 1). Despite this drastic effect on absolute SON stocks, the seagull colony did not change the relative distribution of SON trough the upper $30 \mathrm{~cm}$ of the soil profile. Irrespective of the bird influence, about $35 \%$ of the total SON in deep tephra sands was located in the upper $5 \mathrm{~cm}$, and decreased gradually to about $5 \%$ at $25-30 \mathrm{~cm}$ depth (Fig. 3, Table 2). 
Table 1. Continued.

\begin{tabular}{|c|c|c|c|c|c|c|c|c|c|}
\hline \multirow[b]{2}{*}{ Source } & \multicolumn{8}{|c|}{$\mathrm{C}$ stock (ton ha ${ }^{-1}$ ) } & \multirow[t]{2}{*}{ Unit: $\mathrm{kg} \mathrm{ha}^{-1} \mathrm{yr}^{-1}$} \\
\hline & Shoots & Roots & Moss & Living & Litter & SOC & Dead & Total & \\
\hline \multicolumn{10}{|l|}{ Colony $\times$ depth } \\
\hline Df Numerator & 1 & 1 & 1 & 1 & 1 & 1 & 1 & 1 & 1 \\
\hline Df Denominator & 15 & 15 & 15 & 15 & 15 & 15 & 15 & 15 & 15 \\
\hline$F$ value & 2.78 & 0.24 & 0.63 & 0.03 & 13.63 & 25.42 & 37.69 & 3.29 & 5.92 \\
\hline$p$ value & ns & ns & ns & ns & $* *$ & $* * *$ & $* * *$ & ns & $*$ \\
\hline \multicolumn{10}{|l|}{ Colony } \\
\hline Df Numerator & 1 & 1 & 1 & 1 & - & - & - & 1 & - \\
\hline Df Denominator & 17 & 17 & 17 & 17 & - & - & - & 17 & - \\
\hline$F$ value & 22.06 & 32.70 & 0.40 & 40.40 & - & - & - & 83.14 & - \\
\hline$p$ value & $* * *$ & $* * *$ & ns & $* * *$ & - & - & - & $* * *$ & - \\
\hline \multicolumn{10}{|l|}{ Depth } \\
\hline Df Numerator & 1 & 1 & 1 & 1 & - & - & - & 1 & - \\
\hline Df Denominator & 16 & 16 & 16 & 16 & - & - & - & 16 & - \\
\hline$F$ value & 2.66 & 0.28 & 2.73 & 0.01 & - & - & - & 2.32 & - \\
\hline$p$ value & ns & ns & 0.12 & ns & - & - & - & ns & - \\
\hline \multicolumn{10}{|c|}{$\begin{array}{l}\text { Colony effect on deep } \\
\text { tephra sand }\end{array}$} \\
\hline Df Numerator & - & - & - & - & 1 & 1 & 1 & - & 1 \\
\hline Df Denominator & - & - & - & - & 8 & 8 & 8 & - & 8 \\
\hline$F$ value & - & - & - & - & 11.25 & 126.8 & 206.2 & - & 171.29 \\
\hline$p$ value & - & - & - & - & * & $* * *$ & $* * *$ & - & $* * *$ \\
\hline \multicolumn{10}{|c|}{$\begin{array}{l}\text { Colony effect on shallow } \\
\text { tephra sand }\end{array}$} \\
\hline Df Numerator & - & - & - & - & 1 & 1 & 1 & - & 1 \\
\hline Df Denominator & - & - & - & - & 7 & 7 & 7 & - & 7 \\
\hline$F$ value & - & - & - & - & 5.14 & 30.95 & 24.78 & - & 24.69 \\
\hline$p$ value & - & - & - & - & ns & $* * *$ & $* *$ & - & $* *$ \\
\hline \multicolumn{10}{|c|}{ Depth effect outside colony } \\
\hline Df Numerator & - & - & - & - & 1 & 1 & 1 & - & 1 \\
\hline Df Denominator & - & - & - & - & 8 & 8 & 8 & - & 8 \\
\hline$F$ value & - & - & - & - & 1.89 & 0.00 & 0.00 & - & 0.10 \\
\hline$p$ value & - & - & - & - & ns & ns & ns & - & $\mathrm{ns}$ \\
\hline \multicolumn{10}{|c|}{ Depth effect inside colony } \\
\hline Df Numerator & - & - & - & - & 1 & 1 & 1 & - & 1 \\
\hline Df Denominator & - & - & - & - & 7 & 7 & 7 & - & 7 \\
\hline$F$ value & - & - & - & - & 11.25 & 28.48 & 40.17 & - & 5.15 \\
\hline$p$ value & - & - & - & - & * & $* *$ & **** & ns & ns \\
\hline
\end{tabular}

\subsection{Nitrogen accumulation rate}

The average rate of total $\mathrm{N}$ accumulation (in both living and dead compartments) over the 50 years of island succession was $0.7 \mathrm{~kg} \mathrm{ha}^{-1} \mathrm{yr}^{-1}$ outside the seagull colony and the effect of tephra depth was not significant (Fig. 4, Table 1). In sharp contrast, the seabirds accelerated the $\mathrm{N}$ accumulation rate, with a factor of almost $50-100$, to $36-58 \mathrm{~kg} \mathrm{ha}^{-1} \mathrm{yr}^{-1}$ (Fig. 4). Within the seabird colony, there was no difference in $\mathrm{N}$ accumulation rate between tephra depths (Table 2).

\subsection{Ecosystem biomass and C stocks and SOC concentrations}

The area inside the colony contained 50 times more biomass than the plots outside of the bird colony, irrespective of tephra depth. For C, the area inside the colony contained 29 times more $\mathrm{C}$ than the area not affected by the seabirds on deep tephra sand, and 16 times more $\mathrm{C}$ on shallow tephra sand (Fig. 5, Table 1).

The seabird colony increased all individual stocks of biomass and $\mathrm{C}$, both belowground as aboveground (Fig. 5, Table 1). The living biomass stock was over 50 times larger ( 0.7 vs. 36 ton ha ${ }^{-1}$ outside and inside the colony, respectively), and the living biomass $\mathrm{C}$ stock was almost 70 times higher $\left(0.19\right.$ vs. 13 ton $\mathrm{ha}^{-1}$ outside and inside the colony, respectively) (Fig. 5). The proportion of $\mathrm{C}$ stored in living biomass compared to SOC also shifted drastically; from a $24: 76$ distribution outside the colony, to a $68: 32$ distribution inside the colony.

Tephra depth, however, had only an effect inside the colony. There, the plots on deep tephra sand stored more litter, litter $\mathrm{C}$ and SOC than those on shallow sand layers (Fig. 5, Table 1). The SOC stock in deep tephra sand $\left(10\right.$ ton $\left.\mathrm{Cha}^{-1}\right)$ was more than twice as large than on shallow tephra sand (4 ton $\mathrm{Cha}^{-1}$ ) (Fig. 5). 


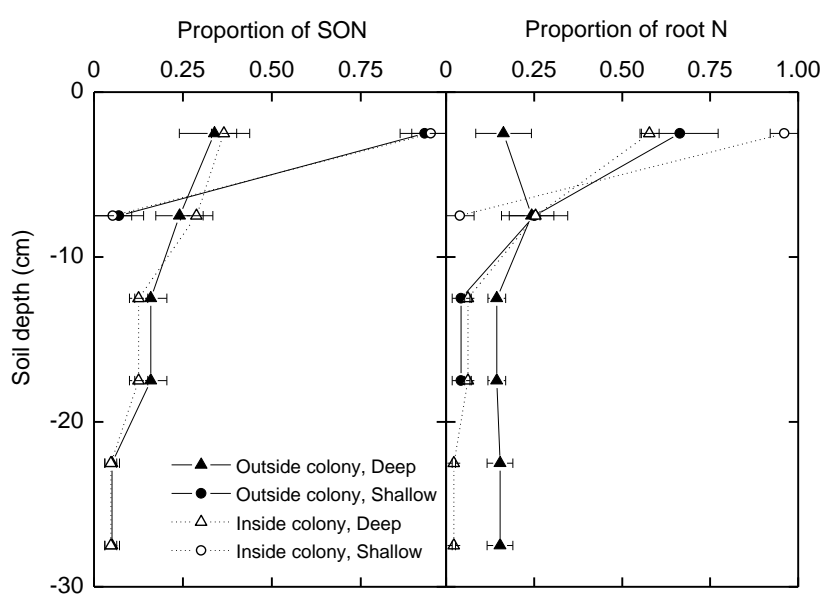

Figure 3. Depth distribution of soil organic nitrogen (SON) and root $\mathrm{N}$ in four ecosystem types on Surtsey. Mean $( \pm \mathrm{SE})$ proportions at each depth layer were calculated relative to the total SON or root $\mathrm{N}$ content in the top $30 \mathrm{~cm}$. Statistical results can be found in Table 2 .

On deep tephra sand, the seabird colony had a pronounced effect on the relative distribution of the roots (Fig. 3). Outside the colony, the roots were evenly distributed throughout the upper $10 \mathrm{~cm}$ of the soil. Inside the colony, however, the roots were concentrated in the top $5 \mathrm{~cm}(57 \%$ of the total root weight within $30 \mathrm{~cm}$ depth), and declined to a fraction of only $4 \%$ between 20 and $30 \mathrm{~cm}$ depth.

The SOC concentration in the upper $5 \mathrm{~cm}$ of the tephra sand outside the colony was $0.12 \pm 0.02 \%$ (error is SE; data not shown). Inside the colony, there was a significant depth effect on SOC concentration in the upper $5 \mathrm{~cm}$ of the tephra sand. On deep tephra sand, the SOC concentration was $0.9 \pm 0.3 \%$, whereas it was as high as $4.6 \pm 0.4 \%$ on shallow tephra sand (errors are SEs; data not shown).

\subsection{Impacts of ecosystem N stock on biomass and C stocks}

There was a highly significant positive linear relationship within the seagull colony between total ecosystem biomass and $\mathrm{C}$ stock and total ecosystem $\mathrm{N}$ stock (Fig. 6), while almost half of the $\mathrm{N}$ and $\mathrm{C}$ was located in the soil (50 and $40 \%$ on deep and shallow soils respectively), and was therefore not directly related to the biomass. An increase of one $\mathrm{g}$ of $\mathrm{N}$ could support an extra $32 \mathrm{~g}$ biomass and $20 \mathrm{~g}$ of ecosystem C. Outside the colony, neither biomass nor $\mathrm{C}$ showed a significant correlation with total $\mathrm{N}$ stock (here, approximately $80 \%$ of $\mathrm{N}$ and $\mathrm{C}$ was located in the soil), but for one $\mathrm{g} \mathrm{N}$, a median of 17 and $12 \mathrm{~g}$ of biomass or $\mathrm{C}$ stock were found (Fig. 6). There was no significant correlation between $\mathrm{R} / \mathrm{S}$ ratio and ecosystem $\mathrm{N}$ stock neither outside nor inside the colony (Fig. 7). The variation in the measured $\mathrm{R} / \mathrm{S}$ ratio was large. The values ranged from 0.1 to 194 outside the colony and from 1.8 to 96 inside (Fig. 7) the colony. The me-

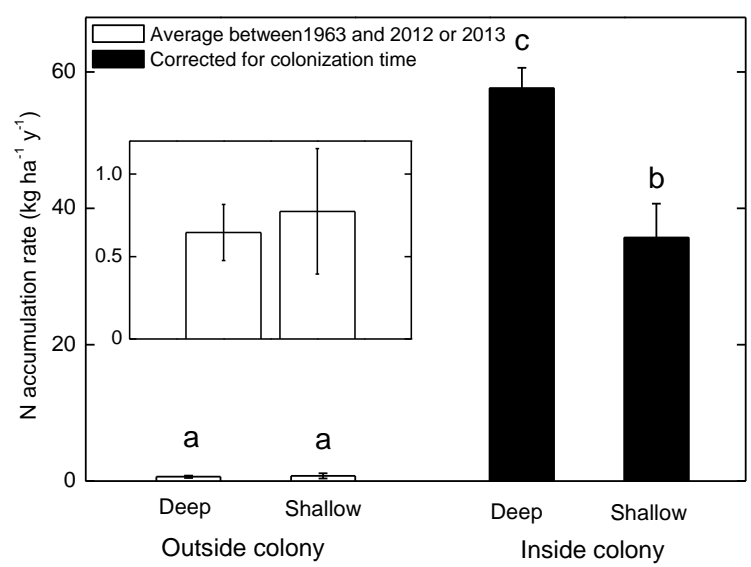

Figure 4. Mean $( \pm \mathrm{SE})$ values of the $\mathrm{N}$ accumulation rate in four ecosystem types on Surtsey. The inserted graph gives values outside the colony in more detail. White bars show the average $\mathrm{N}$ accumulation values between 1963 and the sampling year (2012 or 2013). Black bars show the $\mathrm{N}$ accumulation after the start of seagull colonization. Statistical results are shown in Table 1.

dian R / S ratios were 18 and 5, outside and inside the seabird colony, respectively.

\section{Discussion}

\subsection{Nitrogen accumulation outside the seabird colony}

The mean $\mathrm{N}$ accumulation rate in soil and biomass outside the seabird colony during 50 years since Surtsey first emerged $\left(0.7 \mathrm{~kg} \mathrm{ha}^{-1} \mathrm{yr}^{-1}\right.$, Fig. 4), represents about $50-60 \%$ of the estimated annual atmospheric $\mathrm{N}$ deposition rate in Iceland corrected to $1600 \mathrm{~mm}$ annual precipitation (1.3-1.4 $\mathrm{kg} \mathrm{N} \mathrm{ha}^{-1} \mathrm{yr}^{-1}$ ) (Gislason et al., 1996; Sigurdsson et al., 2005). This estimate of 50-60\% retention is somewhat low compared to the average $\mathrm{N}$ retention in systems under low $\mathrm{N}$ input (75\%, Thomas et al., 2013) and even more so compared to the $>80 \% \mathrm{~N}$ retention in bare dune habitats reported by ten Harkel et al. (1998). This could be explained by the initial lack of plants on the island, resulting in higher leakage during the first years. After establishment of the primary colonizers in the 1970s and 1980s, the total aboveground vegetation cover outside the colony has remained low and stable $(3.0 \% \pm 0.3)$ since the start of detailed measurements in 1994 (Magnússon, unpublished data). Despite the very sparse aboveground vegetation cover, it became evident during sampling that the unvegetated tephra sand areas were fully colonized by roots. Another study, which took place on and around Leymus dunes in the same area outside the seagull colony, but not within our permanent study plots, found similar dense root distribution (Stefansdottir et al., 2014). Therefore, we can assume that after vegetation establishment the $\mathrm{N}$ retention on Surtsey has increased and is now close to the 


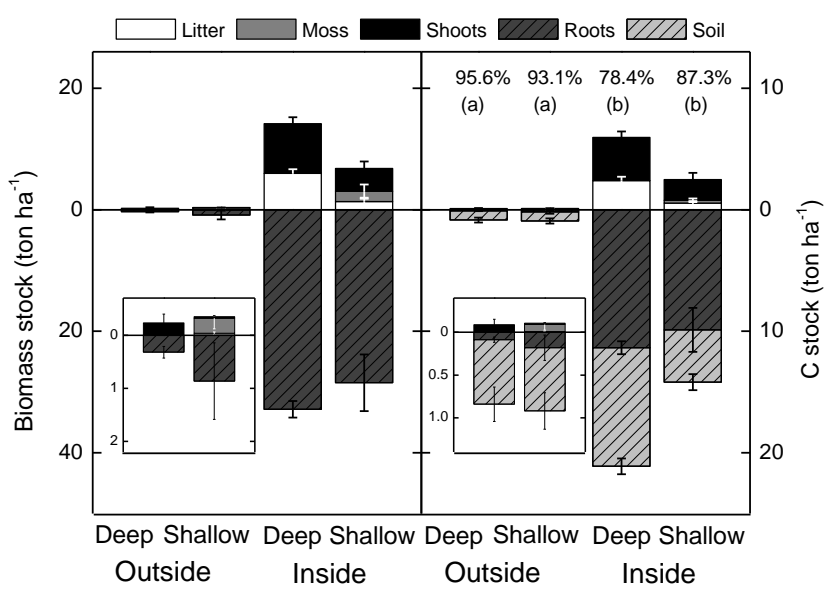

Figure 5. Mean $( \pm \mathrm{SE})$ values of the biomass stock and $\mathrm{C}$ stock of litter, shoots, roots (to $30 \mathrm{~cm}$ depth) and SOC (to $30 \mathrm{~cm}$ depth) in four ecosystem types on Surtsey. The inserted graphs give the values outside the seabird colony in more detail. "Shoots" include aboveground living vascular plant parts. Statistical results are shown in Table 1. Percentages above the graph indicate the $\%$ of total $\mathrm{C}$ that is located belowground. Letters show statistical differences.

$75-80 \%$ reported for ecosystems with low $\mathrm{N}$ inputs (Thomas et al., 2013).

We assume atmospheric deposition to be the main source of $\mathrm{N}$ outside the seabird colony. Additional mechanisms of $\mathrm{N}$ input could be: (1) $\mathrm{N}$ inputs from volcanic processes, (2) chemical weathering of N-containing bedrock, (3) $\mathrm{N}$ input from over-flying birds, (4) symbiotic $\mathrm{N}_{2}$ fixation (5) free living $\mathrm{N}_{2}$ fixation and (6) $\mathrm{N}$ fixation by lichens and biological soil crusts (BSC). Mechanisms (1) and (2) can be largely rejected, since Ponnameruma et al. (1967) showed that the tephra sands of Surtsey did not contain any organic $\mathrm{N}$ and very little inorganic $\mathrm{NH}_{4}$ and $\mathrm{NO}_{3}$; the latter probably mostly originating from rainfall during the first 4 years since the eruption started. This study did report some inorganic $\mathrm{N}$ in recently deposited tephra, which could indicate volcanic N sources (cf. Huebert et al., 1999). However, the concentrations were lower in the older tephra layers, probably indicating leaching due to initial lack of biological activity to retain the $\mathrm{NO}_{3}$. Further, we argue that $\mathrm{N}$ deposited by over-flying birds (3) was of minor importance, as total plant cover did not increase between 1994 and 2012 in any of the permanent plots outside the seabird colony (Magnússon, unpublished data). A steady increase of vegetation cover after 1986 (the establishment of the colony) would be expected if over-flying birds added a substantial amount of N. Also N input mechanisms (4) and (5) were probably of lesser importance as well since, to date, no plant species known to have $\mathrm{N}_{2}$-fixing symbionts have colonized Surtsey (Magnússon et al., 2014), and because the low water retention of the tephra sand and the low soil temperatures would not support large populations of free-living $\mathrm{N}_{2}$ fixing microbes (Zielke et al., 2005; Sorensen et al., 2006). The mean annual soil tem-

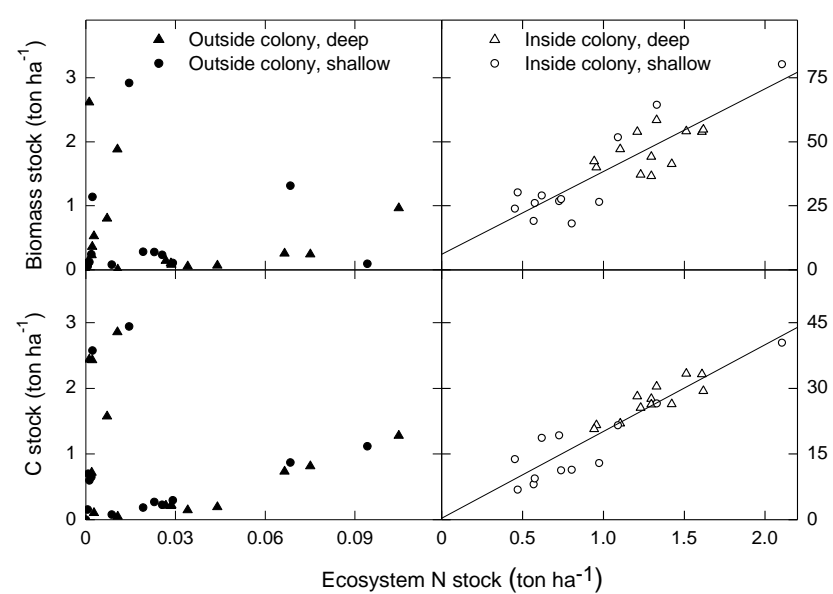

Figure 6. Relationships between ecosystem biomass stocks (upper graphs) and ecosystem C stocks (bottom graphs) and ecosystem $\mathrm{N}$ stocks. Left graphs show the relationship outside the seagull colony, right graphs show the relationship inside the seagull colony. Note the difference in scale of the $y$ axis between the left and the right panel. Correlation function for biomass inside the colony: biomass $=6( \pm 4)+32( \pm 4) *$ ecosystem N stock $(r=0.86$; $t=8.01 ; \mathrm{Df}=22 ; p<0.001)$. Correlation function for $\mathrm{C}$ inside the colony: $\mathrm{C}=0.4( \pm 1.9)+19.8( \pm 1.7) *$ ecosystem $\mathrm{N}$ stock $(r=0.93 ; t=11.75, \mathrm{Df}=22, p<0.001)$. Errors are SEs.

perature and volumetric water content were $7.5^{\circ} \mathrm{C}$ and only $8.4 \%$, respectively, at $5 \mathrm{~cm}$ depth during 2010-2012 (unpublished data). Mechanism (6), N-fixation by lichens or biological soil crusts, must be occurring on Surtsey, as Kristinsson and Heidmarsson (2009) found known $\mathrm{N}_{2}$-fixing species on the island. However, these species had a very limited distribution on the island, and their $\mathrm{N}$ input to the ecosystem is therefore assumed to be negligible for the island as a whole.

\subsection{Nitrogen accumulation inside the seabird colony}

The SON values from Surtsey ranged from 0.03 to 0.65 ton $\mathrm{ha}^{-1}$, and span the whole range that Lin et al. (2000) modeled for Iceland $\left(0.0-0.5\right.$ ton $\left.\mathrm{ha}^{-1}\right)$. This demonstrates the large effect seabirds have had on the N stock on Surtsey in only 27 years. The apparent lack of other major $\mathrm{N}$ inputs on Surtsey, which typically complicate the quantitative estimation of seabird-driven $\mathrm{N}$ input rates, enabled us to calculate a reliable estimate of $\mathrm{N}$ input rates by seabirds from the measured $\mathrm{N}$ stocks and seabird colonization duration.

The seabirds increased the ecosystem $\mathrm{N}$ stock 30-fold during 26-27 years, compared to the area outside the seagull colony, equivalent to an input rate of on average $47 \mathrm{~kg} \mathrm{ha}^{-1} \mathrm{yr}^{-1}$. This value was much higher than we originally hypothesized, but it corresponded almost exactly with the estimate of Bancroft et al. (2005) (50.9 $\mathrm{kg} \mathrm{ha}^{-1} \mathrm{yr}^{-1}$ ) for a Wedge-tailed Shearwaters (Puffinus pacificus) colony on Rottnest Island (West-Australia), who used guano traps to estimate seabird-derived $\mathrm{N}$ deposition. We are not aware 


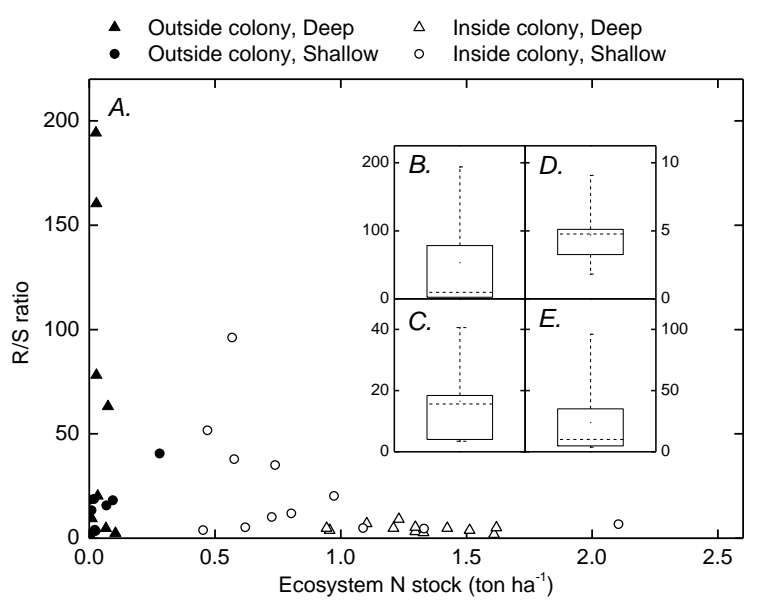

Figure 7. Relationship between R/S ratio (Root/Shoot ratio) and $\mathrm{N}$ stock (a). Central figure shows box plots of the $\mathrm{R} / \mathrm{S}$ ratio on deep tephra sand outside the colony (b), shallow tephra sand outside the colony (c), deep tephra sand inside the colony (d) and shallow tephra sand inside the colony (c). Boxes show 25, 50 and 75 percentile, whiskers show 5 and 95 percentile. Note the differences in scale of the $y$ axes. Samples lacking roots or shoots were excluded from the graphs.

of other studies that attempted to estimate seabird $\mathrm{N}$ input rates, but our own calculations, based on a study of BreuningMadsen et al. (2010), who measured the $\mathrm{N}$ stocks in an established Cormorant colony (24 years) in the Horsens Fjord, Denmark, resulted in even higher $\mathrm{N}$ input rates (an average of $292 \mathrm{~kg} \mathrm{ha}^{-1} \mathrm{yr}^{-1}$ ).

The SON concentration in the upper $10 \mathrm{~cm}$ of soil inside the bird colony at Surtsey $\left(2.5 \mathrm{mg} \mathrm{g}^{-1} \mathrm{DM}\right)$ was higher than what was found by Ligeza and Smal (2003) in perennial colonies of piscivorous birds in northern and eastern Poland $\left(\sim 0.6 \mathrm{mg} \mathrm{g}^{-1} \mathrm{DM}\right)$, but was very similar to that reported by Anderson and Polis (1999) for seabird colonies on hyperarid, naturally nutrient-poor islands in the Gulf of California ( $\left.\sim 2 \mathrm{mg} \mathrm{g}^{-1} \mathrm{DM}\right)$. It must be noted that both these studies investigated longer-lived bird colonies. Given the high organicmatter retention capacity of the Andosols at Surtsey, it might be that SON concentrations increase even further, but this remains speculation.

\subsection{Effect of tephra-layer depth on $\mathrm{N}$ retention}

Even if SON and litter $\mathrm{N}$ accumulation were significantly higher at the deeper tephra sands within the seagull colony, we did not find a significant effect of tephra-layer depth on total $\mathrm{N}$ stock, when biomass-N was included. This suggests a high $\mathrm{N}$ retention potential in the upper centimeters of the tephra sand. This finding contradicts our second hypothesis, that deeper substrates would positively affect $\mathrm{N}$ retention, as was shown by Selmants et al. (2014). Faster succession rates on the deeper tephra sands in Surtsey (Magnússon and Magnússon, 2000; Del Moral and Magnússon, 2014) can there- fore not be explained solely by increased $\mathrm{N}$ accumulation rates.

\subsection{Shifts from belowground to aboveground plant biomass}

Despite the fact that the median R/S ratio outside the colony was almost three times higher than the upper extreme for cool temperate deserts reported by Mokany et al. (2006), it corresponded closely with the mean ratio of 19 reported by (Stefansdottir et al., 2014) for the Leymus area outside the seabird colony. For the grassland inside the colony, the median R/S of 5 did not differ much from the median reported by Mokany et al. (2006) for cool temperate grasslands without bird colonies. Given the more severe nutrient limitation expected for cool temperate grasslands compared to grasslands in a seabird colony, this similar R/S was unexpected. We therefore assume that the low water retention capacity of the sands on Surtsey causes frequent droughts and that the positive impact of drought on R/S offset the negative effect of seabird-driven nutrient inputs (see discussion below).

Changes in nutrient availability can often be detected by looking at R/S ratios (Levang-Brilz and Biondini, 2003; Chu et al., 2006), as increased nutrient availability promotes investment in aboveground plant parts. Therefore, we hypothesized a decrease in $\mathrm{R} / \mathrm{S}$ ratio with increasing ecosystem $\mathrm{N}$ stock. Despite previous research showing negative correlations between $\mathrm{R} / \mathrm{S}$ ratio and nutrient availability in grassland ecosystems (Levang-Brilz and Biondini, 2003; Chu et al., 2006), no such relationship was found on Surtsey, neither inside nor outside the colony. Outside the seabird colony, such a potential relationship might be concealed by the patchiness of the aboveground vegetation, the homogeneous root distribution (Stefansdottir et al., 2014) and the relatively small size of the measurement frames. The combination of these three factors probably explains why we measured several unrealistically high $\mathrm{R} / \mathrm{S}$ ratios, ranging up to 194 . Inside the seabird colony, the lack of relationship between $\mathrm{R} / \mathrm{S}$ and $\mathrm{N}$ stock is possibly due to other factors, such as limiting water availability, overruling the effect of $\mathrm{N}$ availability on the $\mathrm{R} / \mathrm{S}$ ratio. Drought has been reported to be an important determinant of R/S ratios (Donkor et al., 2002; Gianoli et al., 2009; Dreesen et al., 2012) and water infiltration in Andosols is rapid compared to most other soils (Basile et al., 2003), especially when the $\mathrm{C}$ content is below $12 \%$, as is the case on Surtsey (Arnalds, 2008). Therefore, we attribute the absence of a clear nutrient influence on $\mathrm{R} / \mathrm{S}$ ratio to an overruling effect of drought in all occurring nutrient situations.

\subsection{Shifts from belowground to aboveground $\mathrm{N}$ and $\mathrm{C}$ and $\mathrm{N}$-use efficiency}

The clear shift in both $\mathrm{N}$ and $\mathrm{C}$ from belowground to aboveground stocks inside the colony agrees with our hypothesis (iii) that the increase in nutrient availability inside the 
Table 2. Results of two-way ANOVA of the depth distribution of SON and Root N per soil depth, using colony and tephra depth as fixed. Significant source variables $(p<0.05)$ with respect to soil depth are indicated with an asterisk: ns is $p>0.05, * p$ is $0.05-0.01, * * p$ is $0.01-0.001, * * * p<0.001$.

\begin{tabular}{|c|c|c|c|c|c|c|c|c|}
\hline \multirow[b]{3}{*}{ Source } & \multicolumn{5}{|c|}{ SON } & \multicolumn{2}{|c|}{ Root N } & \multirow[b]{3}{*}{$20-30$} \\
\hline & \multicolumn{7}{|c|}{ Soil depth $(\mathrm{cm})$} & \\
\hline & $0-5$ & $5-10$ & $10-20$ & $20-30$ & $0-5$ & $5-10$ & $10-20$ & \\
\hline \multicolumn{9}{|l|}{ Colony $\times$ depth } \\
\hline Df Numerator & 1 & 1 & $\mathrm{n} / \mathrm{a}$ & $\mathrm{n} / \mathrm{a}$ & 1 & 1 & 1 & $\mathrm{n} / \mathrm{a}$ \\
\hline Df Denominator & 11 & 11 & $\mathrm{n} / \mathrm{a}$ & $\mathrm{n} / \mathrm{a}$ & 15 & 15 & 15 & $\mathrm{n} / \mathrm{a}$ \\
\hline$F$ value & 0.01 & 0.63 & $\mathrm{n} / \mathrm{a}$ & $\mathrm{n} / \mathrm{a}$ & 0.28 & 2.06 & 0.20 & $\mathrm{n} / \mathrm{a}$ \\
\hline$p$ value & ns & ns & $\mathrm{n} / \mathrm{a}$ & $\mathrm{n} / \mathrm{a}$ & ns & ns & ns & $\mathrm{n} / \mathrm{a}$ \\
\hline \multicolumn{9}{|l|}{ Colony } \\
\hline Df Numerator & 1 & 1 & 1 & 1 & 1 & 1 & 1 & 1 \\
\hline Df Denominator & 12 & 12 & 6 & 6 & 16 & 16 & 16 & 17 \\
\hline$F$ value & 0.25 & 0.15 & 0.49 & 0.13 & 16.18 & 1.15 & 6.83 & 4.59 \\
\hline$p$ value & ns & ns & ns & ns & $* * *$ & ns & $*$ & * \\
\hline \multicolumn{9}{|l|}{ Depth } \\
\hline Df Numerator & 1 & 1 & $\mathrm{n} / \mathrm{a}$ & $\mathrm{n} / \mathrm{a}$ & 1 & 1 & 1 & $\mathrm{n} / \mathrm{a}$ \\
\hline Df Denominator & 13 & 13 & $\mathrm{n} / \mathrm{a}$ & $\mathrm{n} / \mathrm{a}$ & 17 & 17 & 17 & $\mathrm{n} / \mathrm{a}$ \\
\hline$F$ value & 55.15 & 10.45 & $\mathrm{n} / \mathrm{a}$ & $\mathrm{n} / \mathrm{a}$ & 10.76 & 1.49 & 4.54 & $\mathrm{n} / \mathrm{a}$ \\
\hline$p$ value & $* * *$ & $* *$ & $\mathrm{n} / \mathrm{a}$ & $\mathrm{n} / \mathrm{a}$ & $* *$ & ns & * & $\mathrm{n} / \mathrm{a}$ \\
\hline
\end{tabular}

n/a: not applicable: no SON or Root $\mathrm{N}$ in shallow tephra sand.

colony would stimulate the system to invest more in aboveground growth. This relationship between nutrient availability and growth investment confirms many earlier studies (e.g. Warembourg and Estelrich, 2001; Wang et al., 2008; Gao et al., 2011; Zhou et al., 2014). This shift from below- to aboveground was accompanied by a doubling of the $\mathrm{N}$ - use efficiency; the grassland inside the colony supported $\sim 2$ times more biomass and biomass $\mathrm{C}$ per $\mathrm{g} \mathrm{N}$, compared to the almost unvegetated area outside the colony. This large increase in the N-use efficiency indicated a positive feedback between $\mathrm{N}$ stock and the storage of both biomass and $\mathrm{C}$. This increase was caused by the drastic shift in $\mathrm{C}$ distribution: from a $76: 24$ towards a $32: 68$ proportion in SOC and biomass, respectively. The $\mathrm{C} / \mathrm{N}$ ratio of $\mathrm{SOC}$ was smaller than that of biomass $(10.4 \pm 0.6$ vs. $39.1 \pm 2.3($ mean $\pm \mathrm{SE})$ ), in line with the $\mathrm{C} / \mathrm{N}$ ratios for undisturbed soils reported by Chapin et al. $(2011 ; \sim 14)$ and for leaves reported by Sterner and Elser $(2002 ; \sim 36)$. Hence, the overall C/ N ratio of ecosystems with most $\mathrm{C}$ stored in SOC (such as the noncolonized area) is typically smaller than the overall $\mathrm{C} / \mathrm{N}$ ratio of ecosystems with a high fraction of $\mathrm{C}$ stored in living biomass (such as in the seabird colony).

The reason why higher $\mathrm{N}$-stocks can support more biomass and $\mathrm{C}$ per unit $\mathrm{N}$ remains to be better explored. Several studies on immature volcanic soils in New Zealand, Chile and Japan have found a positive relationship between total $\mathrm{N}$ stock and net $\mathrm{N}$-mineralization rates (and consequently plant available N) (Parfitt et al., 2005; Hirzel et al., 2010; Yamasaki et al., 2011). In the last study, the increased
$\mathrm{N}$-mineralization following $\mathrm{N}$ addition was proved to be correlated with the inhibition of microbial $\mathrm{N}$-immobilization (and consequently decreased competition between plant and microbial $\mathrm{N}$-uptake). This inhibition of $\mathrm{N}$ uptake by microbes was proposed to result from nitrification-induced acidification, increased soil osmotic potential to toxic values and an inhibition of ligninolytic enzyme production. The significant acidification inside the seabird colony on Surtsey (Sigurdsson and Magnússon, 2010) supports this hypothesis, however, further study is needed to investigate the role of microbial $\mathrm{N}$-immobilization in $\mathrm{N}$-availability for plants on Surtsey.

\subsection{Seabird effect on biomass and C stocks}

Aboveground biomass outside the colony $\left(0.13 \pm 0.08\right.$ ton $\left.\mathrm{ha}^{-1}\right)$ was very small and has almost not changed since the first measurements of aboveground biomass in the permanent plots in $1999\left(0.1\right.$ ton ha $\left.{ }^{-1}\right)$ (Magnússon et al., 2009). This invariable aboveground biomass could also indicate relatively few changes in belowground biomass. As biomass degradation is an important source of SOC (Kögel-Knabner et al., 2013), the low biomass production rates outside the seagull colony explain largely the quasi constant SOC concentration and the lack of soil formation. Since 1986, the seabird influence caused an over 50-fold increase of total biomass, from 0.7 to 36 ton $\mathrm{ha}^{-1}$, which corresponds to a shift from values typical for deserts $\left(0-20\right.$ ton $\left.\mathrm{DMha}^{-1}\right)$ to values typical 
for grassland ecosystems (20 to 50 ton $\mathrm{DM} \mathrm{ha}^{-1}$ ); Larcher, 2003). This large increase in only 25 years can largely be attributed to seabird $\mathrm{N}$ input, as there was a strong positive relationship between total ecosystem biomass stock and $\mathrm{N}$ stock (as proxy for available $\mathrm{N}$ ) inside the seabird colony.

The aboveground biomass has been increasing nearly linearly from 1.4 in 1999 to 4.1 ton ha ${ }^{-1}$ in 2007 (Magnússon et al., 2009) to $5.9 \pm 0.9$ ton ha $^{-1}$ (error $=\mathrm{SE}$ ) in 2012-2013. This steady increase indicates that aboveground limitations on growth, such as competition for light and space, were minor compared to the belowground limitations for water and nutrients. This could be expected in a natural grassland ecosystem with relatively low nutrient levels (Kiaer et al., 2013). This was also supported by the strong link between biomass and $\mathrm{N}$ stock.

The $\mathrm{C}$ stock in living biomass showed a clear shift from a typical desert $\mathrm{C}$ stock outside the colony (0.19 ton $\mathrm{ha}^{-1}$; desert ecosystems: $0-10$ ton $\mathrm{ha}^{-1}$; Larcher, 2003) to a stock typical for grassland ecosystems inside the colony (13 ton ha ${ }^{-1}$; grassland ecosystems: $10-25$ ton ha ${ }^{-1}$; Larcher, 2003). However, despite the fact that biomass and living $\mathrm{C}$ stock both have been developing from desert to grassland, the SOC accumulation was lagging behind, and remained far below the average for temperate grassland soils, according to (Schlesinger, 1997; see also 4.7).

\subsection{Did the $\mathrm{N}$ accumulation accelerate soil development?}

Outside the colony, the soil development has proceeded very slowly, as the SOC concentration, which is a reliable indicator of soil development (Kögel-Knabner et al., 2013), had only increased slightly since 1986 in the upper $5 \mathrm{~cm}$ of the tephra sand $(0.12 \pm 0.02 \%$ SOC vs. $0.10 \pm 0.02 \%$ SOC; errors are SEs; Arnalds, unpublished data). When Surtsey had just emerged, the SOC concentration was $0.012 \pm 0.009 \%$ (error is SE; Ponnameruma et al., 1967).

Inside the colony, the SOC concentration has been increasing with a factor of 10 to 60 since the establishment of the colony, from $0.08 \%$ (taking the 1986 value as baseline SOC concentration, as this was the first year of permanent seabird colonization) to $0.9 \pm 0.3 \%$ on deep tephra sand and $4.6 \pm 0.4 \%$ on shallow tephra sand (errors are SEs). This large increase agrees with Stockmann et al. (2013), who hypothesized that priming effects, such as $\mathrm{N}$ addition, might stimulate SOC accumulation in grasslands with a high $\mathrm{R} / \mathrm{S}$ ratio. However, Stockmann et al. (2013) reported that grassland soils typically contain more than 1-3\% SOC. Yang et al. (2014) measured a SOC concentration of 28 up to $58 \%$ in an arid grassland in North China. Despite the rapid buildup, the area inside the bird colony has not yet been lifted to SOC concentrations that are typical for grassland ecosystems. Also, the current stock of SOC of about 4 (shallow) to 10 (deep) ton $\mathrm{ha}^{-1}$ is still marginal compared to the average SOC stock in temperate grassland soils of 192 ton ha ${ }^{-1}$, according to Schlesinger (1997). This indicates that the soil development at Surtsey is still in its first phase. Therefore, we expect the SOC content will continue to accumulate for many centuries before it reaches an equilibrium with the aboveground productivity.

\section{Conclusions}

The calculated annual $\mathrm{N}$ accumulation rate outside the seabird colony amounted to ca. 50-60\% of the estimated atmospheric $\mathrm{N}$ deposition during the past 50 years. This approximates values for systems under low $\mathrm{N}$ input and bare dune habitats. The seabird derived $\mathrm{N}$ input was higher than was expected based on earlier estimates for Surtsey. There was no difference in $\mathrm{N}$ retention between shallow and deep tephra sands, when total $\mathrm{N}$ stocks in biomass and soil were compared. Different succession rates on deep tephra sands within the seagull colony can therefore not be explained by increased $\mathrm{N}$ retention. There was a clear shift from belowground to aboveground biomass, $\mathrm{C}$ and $\mathrm{N}$ inside the colony. Consequently, the $\mathrm{R} / \mathrm{S}$ ratio decreased from very high values outside the colony to more moderate values inside. Further, the $\mathrm{N}$-use efficiency or the amount of $\mathrm{C}$ fixed per $\mathrm{g}$ $\mathrm{N}$, was twice as high inside the colony. The accumulation of SOC, which is an indicator of soil development, was enhanced inside the seabird colony. However, despite biomass and $\mathrm{C}$ stock of living material reaching the typical range of grasslands, the SOC stock remained still small compared to SOC stocks in well-developed grasslands. Therefore, we expect that the SOC stock will continue to increase for many centuries until it reaches an equilibrium with the litter production.

Acknowledgements. This research was supported by the Research Foundation - Flanders (FWO aspirant grant to NL). This work also contributes to the FSC-Sink, CAR-ES and the ClimMani projects. The Surtsey Research Society, Institute of Natural History, Mogilsá - Icelandic Forest Research, Reykir and Keldnaholt Agricultural University of Iceland and the Icelandic Coastguard provided logistical support for the present study. We thank Sturla Fridriksson, Borgthór Magnússon, Sigurdur Magnússon and Erling Ólafsson for generously providing access to their data. Further, we thank Brita Berglund, Baldur Vigfusson, Nadine Calluy, Marijke Van den Bruel, Els Oosterbos and Annemie Vinck for assistance with the lab analyses. I. A. Janssens acknowledges support from the European Research Council Synergy grant 610028.

Edited by: J.-A. Subke 


\section{References}

Aerts, R. and Chapin, F. S.: The mineral nutrition of wild plants revisited: A re-evaluation of processes and patterns, edited by: Fitter, A. H. and Raffaelli, D. G., Adv. Ecolo. Res., 30, 67 pp., 2000.

Anderson, W. B. and Polis, G. A.: Nutrient fluxes from water to land: seabirds affect plant nutrient status on Gulf of California islands, Oecologia, 118, 324-332, 1999.

Arnalds, Ó.: Soils of Iceland, Jökull, 58, 409-422, 2008.

Baldurson, S. and Ingadóttir, A.: Nomination of Surtsey for the UNESCO World Heritage List, Icelandic Insitute of Natural History, Iceland, 2007.

Bancroft, W. J., Garkaklis, M. J., and Roberts, J. D.: Burrow building in seabird colonies: a soil-forming process in island ecosystems, Pedobiologia, 49, 149-165, 2005.

Basile, A., Mele, G., and Terribile, F.: Soil hydraulic behaviour of a selected benchmark soil involved in the landslide of Sarno 1998, Geoderma, 117, 331-346, 2003.

Bowman, D. C., Devitt, D. A., Engelke, M. C., and Rufty, T. W.: Root architecture affects nitrate leaching from bentgrass turf, Crop Sci., 38, 1633-1639, 1998.

Breuning-Madsen, H., Ehlers-Koch, C., Gregersen, J., and Lojtnant, C. L.: Influence of perennial colonies of piscivorous birds on soil nutrient contents in a temperate humid climate, Geogr. Tidsskr., 110, 25-35, 2010.

Chapin, F. S., Matson, P. A., and Vitousek, P.: Principles of terrestrial ecosystem ecology, Springer, 4, 513 pp., 2011.

Chu, Y., Yu, F. H., and Dong, M.: Clonal plasticity in response to reciprocal patchiness of light and nutrients in the stoloniferous herb Glechoma longituba L, J. Integr. Plant Biol., 48, 400-408, 2006.

del Moral, R. and Magnússon, B.: Surtsey and Mount St. Helens: a comparison of early succession rates, Biogeosciences, 11, 2099-2111, doi:10.5194/bg-11-2099-2014, 2014.

Deluca, T. H. and Boisvenue, C.: Boreal forest soil carbon: distribution, function and modelling, Forestry, 85, 161-184, 2012.

Donkor, N. T., Bork, E. W., and Hudson, R. J.: Bromus-Poa response to defoliation intensity and frequency under three soil moisture levels, Can. J. Plant Sci., 82, 365-370, 2002.

Dreesen, F. E., De Boeck, H. J., Janssens, I. A., and Nijs, I.: Summer heat and drought extremes trigger unexpected changes in productivity of a temperate annual/biannual plant community, Environ. Exp. Bot., 79, 21-30, 2012.

Ellis, J. C., Farina, J. M., and Witman, J. D.: Nutrient transfer from sea to land: the case of gulls and cormorants in the Gulf of Maine, J. Anim. Ecol., 75, 565-574, 2006.

Elser, J. J., Bracken, M. E. S., Cleland, E. E., Gruner, D. S., Harpole, W. S., Hillebrand, H., Ngai, J. T., Seabloom, E. W., Shurin, J. B., and Smith, J. E.: Global analysis of nitrogen and phosphorus limitation of primary producers in freshwater, marine and terrestrial ecosystems, Ecol. Lett., 10, 1135-1142, 2007.

Gao, Y. Z., Chen, Q., Lin, S., Giese, M., and Brueck, H.: Resource manipulation effects on net primary production, biomass allocation and rain-use efficiency of two semiarid grassland sites in Inner Mongolia, China, Oecologia, 165, 855-864, 2011.

Gianoli, E., Quezada, I. M., and Suarez, L. H.: Leaf damage decreases fitness and constrains phenotypic plasticity to drought of a perennial herb, Acta Ecol., 35, 752-757, 2009.
Gislason, S. R., Arnorsson, S., and Armannsson, H.: Chemical weathering of basalt in southwest Iceland: Effects of runoff, age of rocks and vegetative/glacial cover, Am. J. Sci., 296, 837-907, 1996.

Grime, J. P.: Evidence for the existence of three primary strategies in plants and its relevance to ecologiecal and evolutionary theory, The American Naturalist, 111, 1169-1194, 1977.

Gruner, D. S., Smith, J. E., Seabloom, E. W., Sandin, S. A., Ngai, J. T., Hillebrand, H., Harpole, W. S., Elser, J. J., Cleland, E. E., Bracken, M. E. S., Borer, E. T., and Bolker, B. M.: A crosssystem synthesis of consumer and nutrient resource control on producer biomass, Ecol. Lett., 11, 740-755, 2008.

Hahn, S., Bauer, S., and Klaassen, M.: Estimating the contribution of carnivorous waterbirds to nutrient loading in freshwater habitats, Freshwat. Biol., 52, 2421-2433, 2007.

Hendriksson, L. E.: Effects of nitrogen, phosphorus, and potassium to Surtsey lava soils on the growth of a test plant (Arena salina, L), Acta Botanica Islandica, 4, 36-43, 1976.

Hirzel, J., Undurraga, P., and Walter, I.: Nitrogen mineralization and released nutrients in a volcanic soil amended with poultry litter, Chil. J. Agr. Res., 70, 113-121, 2010.

Huebert, B., Vitousek, P., Sutton, J., Elias, T., Heath, J., Coeppicus, S., Howell, S., and Blomquist, B.: Volcano fixes nitrogen into plant-available forms, Biogeochemistry, 47, 111-118, 1999.

Jakobsson, S. P.: The geology and petrography of the Vestmann Islands: A preliminary report, Surtsey Research Progress, 4, 113-139, 1968.

Jakobsson, S. P.: Petrology of recent basalts of the eastern volcanic zone, Iceland, Icelandic Museum of Natural History, 1979.

Kiaer, L. P., Weisbach, A. N., and Weiner, J.: Root and shoot competition: a meta-analysis, J. Ecol., 101, 1298-1312, 2013.

Kögel-Knabner, I., Bens, O., Hüttl, R. F., Fischer, T., Dümig, A., and Spröte, R.: Initial stages of humus development, Ecosystem Development, 4, 25-35, 2013.

Kristinsson, H. and Heidmarsson, S.: Colonization of lichens on Surtsey 1970-2006, Surtsey Research, 12, 81-104, 2009.

Larcher, W.: Physiological plant ecology, Ecophysiology and stress physiology of functional groups, Springer, 4, 514 pp., 2003.

Levang-Brilz, N. and Biondini, M. E.: Growth rate, root development and nutrient uptake of 55 plant species from the Great Plains Grasslands, USA, Plant Ecol., 165, 117-144, 2003.

Li, X. and Han, S.: Preservation of broadleaf species in Korean pine (Pinus koraiensis) plantations affects soil properties, carbon storage, biomass allocation, and available nitrogen storage, Can. J. Forest Res. , 38, 2227-2235, 2008.

Ligeza, S. and Smal, H.: Accumulation of nutrients in soils affected by perennial colonies of piscivorous birds with reference to biogeochemical cycles of elements, Chemosphere, 52, 595-602, 2003.

Lin, B. L., Sakoda, A., Shibasaki, R., Goto, N., and Suzuki, M.: Modelling a global biogeochemical nitrogen cycle in terrestrial ecosystems, Ecol. Model., 135, 89-110, 2000.

Long, Z. T., Fegley, S. R., and Peterson, C. H.: Fertilization and plant diversity accelerate primary succession and restoration of dune communities, Plant Ecol., 214, 1419-1429, 2013a.

Long, Z. T., Fegley, S. R., and Peterson, C. H.: Suppressed recovery of plant community composition and biodiversity on dredged fill of a hurricane-induced inlet through a barrier island, J. Coast. Conservation, 17, 493-501, 2013b. 
Magnússon, B. and Magnússon, S. H.: Vegetation succession on Surtsey, Iceland, during 1990-1998 under the influence of breeding gulls, Surtsey Research, 11, 9-20, 2000.

Magnússon, B., Magnússon, S. H., and Fridriksson, S.: Developments in plant colonization and succession on Surtsey during 1999-2008, Surtsey Research, 12, 57-76, 2009.

Magnússon, B., Magnússon, S. H., Ólafsson, E., and Sigurdsson, B. D.: Plant colonization, succession and ecosystem development on Surtsey with reference to neighbouring islands, Biogeosciences, 11, 5521-5537, doi:10.5194/bg-11-5521-2014, 2014.

Marteinsdottir, B., Svavarsdottir, K., and Thorhallsdottir, T. E.: Development of vegetation patterns in early primary succession, $\mathrm{J}$. Veg. Sci., 21, 531-540, 2010.

Mokany, K., Raison, R. J., and Prokushkin, A. S.: Critical analysis of root: shoot ratios in terrestrial biomes, Global Change Biol., 12, 84-96, 2006.

Nie, Y., Liu, X., Wen, T., Sun, L., and Emslie, S. D.: Environmental implication of nitrogen isotopic composition in ornithogenic sediments from the Ross Sea region, East Antarctica: Delta N-15 as a new proxy for avian influence, Chem. Geol., 363, 91-100, 2014.

Olff, H., Huisman, J., and Vantooren, B. F.: Species dynamics and nutrient accumulation during early primary succession in coastal sand dunes, J. Ecol., 81, 693-706, 1993.

Parfitt, R. L., Ross, D. J., Coomes, D. A., Richardson, S. J., Smale, M. C., and Dahlgren, R. A.: N and P in New Zealand soil chronosequences and relationships with foliar $\mathrm{N}$ and $\mathrm{P}$, Biogeochemistry, 75, 305-328, 2005.

Petersen, A.: Formation of a bird community on a new island, Surtsey, Iceland, Surtsey Research, 12, 133-148, 2009.

Polis, G. A. and Hurd, S. D.: Linking marine and terrestrial food webs: Allochthonous input from the ocean supports high secondary productivity on small islands and coastal land communities, Am. Nat., 147, 396-423, 1996.

Ponnameruma, C., Young, R. S., and Caren, L. D.: Some chemical and microbiological studies of Surtsey, Surtsey Research Progress Report 3, 70-80, 1967.

Raab, T., Kruemmelbein, J., Schneider, A., Gerwin, W., Maurer, T., and Naeth, M. A.: Initial ecosystem processes as key factors of landscape development - a review, Phys. Geogr., 33, 305-343, 2012.

Reich, P. B. and Oleksyn, J.: Global patterns of plant leaf $\mathrm{N}$ and $\mathrm{P}$ in relation to temperature and latitude, P. Natl. Acad. Sci. USA, 101, 11001-11006, 2004.

Schlesinger, W. H.: Biochemistry, An analysis of global change, Academic Press, 2, 588 pp., 1997.

Selmants, P. C., Zavaleta, E. S., and Wolf, A. A.: Realistic diversity loss and variation in soil depth independently affect communitylevel plant nitrogen use, Ecology, 95, 88-97, 2014.

Sigurdsson, A. S., Magnússon, S. H., Thorlacius, J. M., Hjartarson, H., Jónsson, P., Sigurdsson, B. D., and H., Ó.: Integrated monitoring at Litle-Skard, Iceland, in: Project Overview 1996-2004, edited by: Umhverfisstofnun, Reykjavik, Iceland, 2005.

Sigurdsson, B. D. and Magnusson, B.: Effects of seagulls on ecosystem respiration, soil nitrogen and vegetation cover on a pristine volcanic island, Surtsey, Iceland, Biogeosciences, 7, 883-891, doi:10.5194/bg-7-883-2010, 2010.

Sorensen, P. L., Jonasson, S., and Michelsen, A.: Nitrogen fixation, denitrification, and ecosystem nitrogen pools in relation to vege- tation development in the subarctic, Arct. Antarct. Alp. Res., 38, 263-272, 2006.

Stefansdottir, G., Aradottir, A. L., and Sigurdsson, B. D.: Accumulation of nitrogen and organic matter during primary succession of Leymus arenarius dunes on the volcanic island Surtsey, Iceland, Biogeosciences, 11, 5763-5771, doi:10.5194/bg-11-57632014, 2014.

Sterner, R. W. and Elser, J. J.: Ecological stoichiometry, The biology of elements from molecules to the biosphere, Princeton University Press, 1, 439 pp., 2002.

Stockmann, U., Adams, M. A., Crawford, J. W., Field, D. J., Henakaarchchi, N., Jenkins, M., Minasny, B., McBratney, A. B., de Courcelles, V. D., Singh, K., Wheeler, I., Abbott, L., Angers, D. A., Baldock, J., Bird, M., Brookes, P. C., Chenu, C., Jastrowh, J. D., Lal, R., Lehmann, J., O’Donnell, A. G., Parton, W. J., Whitehead, D., and Zimmermann, M.: The knowns, known unknowns and unknowns of sequestration of soil organic carbon, Agric. Ecosyst. Environ., 164, 80-99, 2013.

Storm, C. and Suess, K.: Are low-productive plant communities responsive to nutrient addition? Evidence from sand pioneer grassland, J. Veg. Sci., 19, 343-354, 2008.

ten Harkel, M. J., van Boxel, J. H., and Verstraten, J. M.: Water and solute fluxes in dry coastal dune grasslands: the effects of grazing and increased nitrogen deposition, Plant Soil, 202, 1-13, 1998.

Thomas, R. Q., Zaehle, S., Templers, P. H., and Goodale, C. L.: Global patterns of nitrogen limitation: confronting two global biogeochemical models with observations, Global Change Biol., 19, 2986-2998, 2013.

Thuys, R., Janssens, I. A., and Leblans, N. I. W.: How do plant traits change alongside a soil chronosequence on Icelandic islands?, Master, Plant and Vegetation Ecology, University of Antwerp, Antwerpen, 66 pp., 2014.

Trapletti, A., Hornik, K., and LeBaron, B.: Tseries: time series analysis and computational finance, $\mathrm{R}$ package version $0,10-30$, 2012.

Turlach, B. A.: Quadprog: functions to solve quadratic programming problems, R package version 1, 5-4, 2011.

Vitousek, P. M. and Farrington, H.: Nutrient limitation and soil development: Experimental test of a biogeochemical theory, Biogeochemistry, 37, 63-75, 1997.

Vitousek, P. M., Matson, P. A., and Vancleve, K.: Nitrogen availability and nitrification during succession - primary, secondary, and old-field seres, Plant Soil, 115, 229-239, 1989.

Vitousek, P. M., Walker, L. R., Whiteaker, L. D., and Matson, P. A.: Nutrient limitations to plant-growth during primary succession in Hawaii-volcanos-national-park, Biogeochemistry, 23, 197-215, 1993.

Walker, L. R. and Del Moral, R.: Primary succession and ecosystem rehabilitation, Cambridge University Press, Cambridge, 2003.

Walker, L. R., Clarkson, B. D., Silvester, W. B., and Clarkson, B. R.: Colonization dynamics and facilitative impacts of a nitrogenfixing shrub in primary succession, J. Veg. Sci., 14, 277-290, 2003.

Wang, C. T., Cao, G. M., Wang, Q. L., Jing, Z. C., Ding, L. M., and Long, R. J.: Changes in plant biomass and species composition of alpine Kobresia meadows along altitudinal gradient on the Qinghai-Tibetan Plateau, Sci. China Ser. C, 51, 86-94, 2008.

Warembourg, F. R. and Estelrich, H. D.: Plant phenology and soil fertility effects on below-ground carbon allocation for an annual 
(Bromus madritensis) and a perennial (Bromus erectus) grass species, Soil Biol. Biochem., 33, 1291-1303, 2001.

Yamasaki, A., Tateno, R., and Shibata, H.: Effects of carbon and nitrogen amendment on soil carbon and nitrogen mineralization in volcanic immature soil in southern Kyushu, Japan, J.Forest Res., 16, 414-423, 2011.

Yang, R., Su, Y., Wang, M., Wang, T., Yang, X., Fan, G., and Wu, T.: Spatial pattern of soil organic carbon in desert grasslands of the diluvial-alluvial plains of northern Qilian Mountains, Journal of Arid Land, 6, 136-144, 2014.
Zeileis, A., Grothendieck, G., Ryan, J. A., and Andrews, F.: Zoo: S3 infrastructure for regular and irregular time series (Z's ordered observations), R package version 1, 7-9, 2012.

Zhou, X. B., Zhang, Y. M., and Niklas, K. J.: Sensitivity of growth and biomass allocation patterns to increasing nitrogen: a comparison between ephemerals and annuals in the Gurbantunggut Desert, north-western China, Ann. Bot., 113, 501-511, 2014.

Zielke, M., Solheim, B., Spjelkavik, S., and Olsen, R. A.: Nitrogen fixation in the high arctic: Role of vegetation and environmental conditions, Arct. Antarct. Alp. Res., 37, 372-378, 2005. 